\title{
The Effect of Intangible Asset, Capacity of Financial Resource and Regulation. Evidence from Financial Performance of Small Business Firms
}

\author{
Nur Vita Opu, Mahfudnurnajamuddin, Ratna Dewi, and Mapparenta
}

\section{ABSTRACT}

\begin{abstract}
The purpose of this study was to examine and analyze the effect of intangible assets, financial resources, and regulations on the financial performance of small businesses firms in Balikpapan. The development of Balikpapan City with many national and international events has led to the development of the small business sector in this city. This informal sector is a form of business that really helps the family economy. The research samples were 80 units of small businesses. Data collection was conducted using questionnaires and techniques to examine hypotheses it was used descriptive analysis and regression analysis using SPSS 24 . The results show that intangible assets and regulations affect financial performance while financial resources have no effect on financial performance.
\end{abstract}

Keywords: Financial resource, intangible asset, regulation, small business.

\author{
Submitted : November 15, 2021 \\ Published : December 09, 2021 \\ ISSN: 2507-1076 \\ DOI: $10.24018 /$ ejbmr.2021.6.6.1167 \\ Nur Vita Opu * \\ Universitas Muslim Indonesia, Indonesia. \\ (e-mail: nur.vita@poltekba.ac.id) \\ Mahfudnurnajamuddin \\ Universitas Muslim Indonesia, Indonesia \\ Ratna Dewi \\ Universitas Muslim Indonesia, Indonesia \\ Mapparenta \\ Universitas Muslim Indonesia, Indonesia \\ *Corresponding Author
}

\section{INTRODUCTION}

Small businesses are recognized by researchers as the main source of economic growth and development. Globally, small businesses can significantly contribute to innovation, income distribution, and poverty reduction. Small Business is recognized as having a very vital role in economic development and growth. Based on 2017 data, it is stated that the number of small businesses is 757,090 business units, absorbing a workforce of 116,673,416 (97.02\%). Donate Gross Domestic Product of Rp. 5,425.4 trillion (57.08\%) and foreign exchange of Rp. 298.2 trillion (14.17\%). They also provide extended scope for entrepreneurs, increase economic conversion, and have tremendous potential to promote sustainable development (Peter et al., 2019).

Consider the vital role of small businesses; developing countries such as Indonesia through government policies build continuous and sustainable development strategies to increase small businesses by optimizing their resources.

Previous studies have shown various predictors of financial performance (Fauzi et al., 2017; Harash et al., 2014). According to Mulyono (2013), the performance of small businesses depends on the resources and capabilities controlled by the business itself. (Nangoli et al., 2013) also revealed that the failure of small businesses resulted from inadequate supervision, managerial, high competition, low saving culture, poor financial discipline, high taxes, and limited commitment in running a business. Furthermore, Vijay \& Ajay (2011) reveal that entrepreneurial competence is very important in enabling small businesses to interact effectively and efficiently both internally and externally to achieve the desired performance. Company capability is a resource of performance for small businesses and can lead to sustainable performance (Ambrosini \& Bowman, 2009; Barney, 2007) reports that capabilities are accumulated over time can act as a driving force for small businesses to undertake some opportunities.

Access to finance is also important in improving performance (Harash et al., 2014). Thus, businesses that have good financial access tend to have better performance than businesses that rely on their capital. So far, most of the research conducted has focused on large businesses. In addition, there are research limitations related to the combined effect of owned assets, access to financing, and government regulations in improving company performance. Gaps occur from several research results in this literature.

Based on the findings of the problems above, this research needs to be developed further by analyzing the role of intangible assets, financial resources, and regulations on the financial performance of small businesses in Balikpapan. Financial performance assessment in a business is very important for business continuity. It is known that the development of businesses, including small businesses, is indicated by the achievement of financial performance. In small businesses, simple financial performance can be described by achieving sales targets, returns of investment, ability to pay debts, earning profits, and growth performance.

\section{THEORETICAL STUDY}

\section{A. Intangible Assets}

This study refers to the Resource Based View Theory 
(RBV) to explain the important role of intangible assets in today's era where the market is increasingly competitive and constantly changing. This theory also argues that companies that have unusual, valuable, and unique resources can increase sales and earn profits. Intangible assets can be defined as something owned by a person or company that cannot be seen (PSAK, 2013). Intangible assets do not have physical substance like equipment or wealth but become one of the important long-term assets for an organization or company. From various indicators of intangible assets, the ones used in this study consist of human capital and customer capital.

Human capital is defined as the ability and expertise or intellectual property; innovation capital is the creative power of the organization to create something of value. customer or marketing capital in delivering value to customers such as network marketing, service quality, organizational reputation, brand, copyright, and license.

\section{B. Financial Resources}

Sources of capital come from the ability to access financial sources for business development. The ability to increase capital and the ability to access financing sources, whether provided by banks or other financing sources (El-Hamidi, 2011).

\section{Regulation}

Regulation is a set of rules to control an institution/organization made to be free from violations and obeyed by all its members. According to Koop \& Lodge (2017) regulation is a rule made by the government or other authorities to control the way people behave. From the various regulatory indicators, the ones used in this study consist of business license regulations and funding regulations.

\section{Financial Performance}

Financial performance is an illustration of the achievement of the company's success can be interpreted as the results that have been achieved on various activities. Performance as a means to evaluate progress made over a certain period of time and as information for future planning and decision making for improvement and identifying strengths and weaknesses on profitability, firm size, and growth (Garengo et al., 2005).

Assessment of financial performance in small businesses is very important to do for business continuity. Small-scale companies describe the development of their business with simple financial performance with indicators, those are sales and profitability including sales based on the activity ratio, which measures the effectiveness of the company is utilizing its resources, the more effective it is in utilizing funds, the faster the turnover of the funds.

The activity ratio is expressed as a comparison of sales with various elements of assets. While profits are based on profitability ratios, it is used to measure the level of profit that can be generated by the company. The greater the profit obtained the better the management of the company is, by looking at the net profit margin and the return on total assets/investment (ROA/ROI) (Financial accounting standards PSAK, 2013).

\section{RESEARCH METHODS}

This study uses a cross-sectional and correlational approach to establish the compound effects of intangible assets, access to finance, and government support on the financial performance of small businesses in Balikpapan. The type of data used in this study is primary data taken from small business owners in Balikpapan. The populations in this study were all small entrepreneurs in Balikpapan. While the samples in this study are businesses aged more than 5 years. Sample selection was conducted by convenience sampling method.

This study uses a quantitative approach. This study was designed using a descriptive verification type of research. Descriptive research is research that aims to obtain a description of an object, in this case, is a description of the research variables. Verificative research is research that aims to determine the effect between variables through hypothesis testing in this case is the effect of intangible assets, financial resource capacity, regulation on the financial performance of small businesses.

The data collection method used in this study was by distributing questionnaires to small business entrepreneurs. The variables used in this study were measured using a Likert scale with a scale of 1-5 (1=strongly disagree to 5=strongly agree). The questionnaire was directly distributed to the business owner. One of the answers in the questionnaire must be chosen by business owners. The dependent variable in this study is financial performance, while the independent variables are intangible assets, financial resources, and regulations.

Data analysis related to testing funds using the statistical method with the help of SPSS in the form of frequency distribution, validity, reliability of the proposed questionnaire, analyzing the results of the regression and analyzing the results of interviews in accordance with the research objectives, including:

\section{A. Descriptive Statistics}

Descriptive statistics are statistics that describe phenomena or characteristics of the data (Jogiyanto, 2013). These statistics are used to provide an overview of the demographics of the respondents (age, gender, work experience) and a description of the research variables (financial resources, intangible assets, and managerial performance) that show the range, median, mean, and standard deviation.

\section{B. Instrument Quality Test}

The quality of the data generated from research instruments can be evaluated through validity and reliability tests.

\section{Validity Test}

Validity test is used to measure the validity of a questionnaire. If the statement in the questionnaire is able to reveal factors measured by the questionnaire it is considered valid for a questionnaire that contains several statements as used in this study, valid meaning means that each statement item that composes the questionnaire has a high correlation.

The size of the relationship is reflected by the correlation of answers between statements, with a significant rate of $5 \%$. If $r_{\text {count }}$ is positive and $r_{\text {count }}>r_{\text {table }}$, then the statement item is 
valid. If $r_{\text {count }}$ is negative and $r_{\text {count }}<r_{\text {table }}$, the question item is not valid.

\section{Reliability Test}

Reliability means trustworthiness, consistency, and so on. The reliability test of the research instrument (questionnaire) was conducted to test whether the measurement results are reliable, in this case, the respondent's answer to the statement should be consistent from time to time. In this study, the reliability test was carried out using Cronnbach's Alpha method. The questionnaire is declared reliable if it has a Cronbach's Alpha value greater than 0.70 (Sugiyono, 2016).

\section{E. Normality Test}

Normality test is needed to find out whether the error of the regression model is normally distributed or not. The error of the regression model must meet this assumption of normality. In this study, the statistical test used to test the normality of the residuals was the Kolmogorov-Smirnov (K-S) nonparametric statistical test. If the significant value is $<0.05$, the residual data is not normally distributed, or the regression does not meet the normality assumption. Conversely, if the significant value is $>0.05$, the residual data is normally distributed, or the regression meets the normality assumption (Jogiyanto, 2013).

\section{F. Multicollinearity Test}

According to Ghozali (2014) this test is used to determine whether there is a correlation between the independent variables in the regression model. To detect multicollinearity, the regression model can be seen from the tolerance value or Variance Inflation Factor (VIF). The criteria used is if the VIF value is around 1 or has a tolerance close to 1 , then it is considered that there is no multicollinearity problem.

\section{G. Heteroscedasticity Test}

The heteroscedasticity test aims to test whether in a regression model there is an inequality of variance and residuals from one observation to another (Ghozali, 2006:105). If the variance from one observation to another observation remains, it is called homoscedasticity and if it is different, it is called heteroscedasticity. To detect heteroscedasticity, the glacier test can be carried out by regressing the absolute value of the residual to the independent variable (Ghozali, 2006: 108). If the significant value is $>0.05$, then it is said that there is no heteroscedasticity.

\section{H. Hypothesis Test}

The coefficient of determination $\left(\mathrm{R}^{2}\right)$ is a coefficient that shows the percentage of the effect of the independent variable on the dependent variable. The significance level used in this study was 5\% (Ghozali, 2013).

\section{T-test}

In this study, a t-test was conducted with the help of Statistical Product and Service Solution (SPSS) to support the tested hypothesis. The $t_{\text {test }}$ is a statistical test that basically shows how far the effect of the independent variables individually in explaining the dependent variable. With the retrieval criteria, if the statistical significance level is less than $0.05(5 \%)$, therefore $\mathrm{Ha}$ is rejected.

\section{J. F-test}

The $\mathrm{F}_{\text {statistical }}$ test is used to see whether or not the regression model used is acceptable. With the provisions, if $\mathrm{F}_{\text {count }}>\mathrm{F}_{\text {table }}$ with p-value $(\alpha=0.05)$, then the regression model can be accepted and used to test the hypothesis and vice versa.

\section{K. Multiple Linear Regression Model}

This analysis is used to examine the effect of two or more independent variables on the dependent variable (Ghozali, 2013). The analysis in this study is used to examine the effect of intangible assets, financial resources, and regulations on the financial performance of small businesses in Balikpapan. The statistical equations used are:

$$
\mathrm{KK}=\mathrm{a}+\beta 1 \mathrm{ATB}+\beta 2 \mathrm{SDF}+\beta 3 \mathrm{REG}+\mathrm{e}
$$

KK = Financial Performance (Dependent Variable); $\mathrm{A}=$ Constant;

$\beta 1, \beta 2, \beta 3=$ Regression coefficient;

ATB = Intangible asset (Independent Variable);

SDF = Financial resource (Independent Variable);

REG = Regulation (Independent Variable);

$\mathrm{e}=$ error term.

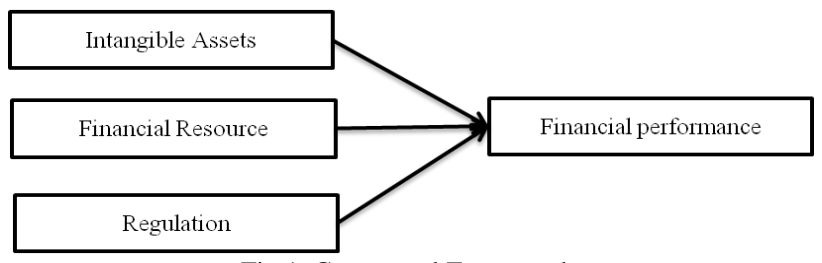

Fig 1. Conceptual Framework.

\section{Hypothesis}

$\mathrm{H}_{1}$ : Intangible assets have a significant positive effect on the financial performance of small businesses

$\mathrm{H}_{2}$ : Financial Resources has a significant positive effect on the financial performance of small businesses

$\mathrm{H}_{3}$ : Regulation has a significant positive effect on the financial performance of small businesses

TABLE I: INTANGIBLE ASSETS INSTRUMENT, FINANCIAL RESOURCE, AND FINANCIAL PERFORMANCE

\begin{tabular}{|c|c|c|c|}
\hline Variable & Indicator & $\begin{array}{l}\text { Number of } \\
\text { statements }\end{array}$ & Scale \\
\hline \multirow{2}{*}{ Intangible assets } & $\begin{array}{l}\text { Human } \\
\text { Capital }\end{array}$ & 1 & Likert \\
\hline & $\begin{array}{l}\text { Customer } \\
\text { Capital }\end{array}$ & 2 & Likert \\
\hline \multirow{3}{*}{ Financial resource } & $\begin{array}{l}\text { Capability } \\
\text { to Improve } \\
\text { Capital }\end{array}$ & 3 & Likert \\
\hline & Ability to & & \\
\hline & $\begin{array}{l}\text { Access } \\
\text { Financial } \\
\text { Resource }\end{array}$ & 4 & Likert \\
\hline \multirow[t]{2}{*}{ Regulation } & $\begin{array}{l}\text { Regulation } \\
\text { of business } \\
\text { permit }\end{array}$ & 5 & Likert \\
\hline & $\begin{array}{l}\text { Financial } \\
\text { regulation }\end{array}$ & 6 & Likert \\
\hline \multirow{2}{*}{$\begin{array}{l}\text { Financial } \\
\text { performance }\end{array}$} & Activity & 7 & Likert \\
\hline & Profitability & 8 & Likert \\
\hline
\end{tabular}




\section{RESULTS AND DISCUSSION}

The populations in this study are small businesses in Balikpapan city. The sample selection in this study was conducted by using a convenience sampling technique

\begin{tabular}{lc}
\multicolumn{2}{c}{ TABLE II: NUMBER OF QUESTIONNAIRES } \\
\hline \hline \multicolumn{1}{c}{ Description } & Number \\
\hline Distributed questionnaire & 85 \\
Not returned questionnaire & 1 \\
Incomplete questionnaire & 4 \\
Completed/processed questionnaire & 80 \\
\hline \hline
\end{tabular}

Based on the data obtained through the distribution of questionnaires, it shows that the information about the small businesses used as samples is the type of business and the age of the business.

TABLE III: DESCRIPTION OF SMALL BUSINESS

\begin{tabular}{cccc}
\hline \hline No & Description & $\begin{array}{c}\text { Number of } \\
\text { respondents }\end{array}$ & Percentage \\
\hline 1 & Type of business & \\
\hline \multirow{2}{*}{$\begin{array}{c}\text { Trading } \\
\text { Accommodation, Food } \\
\text { and Beverage }\end{array}$} & 59 & $74 \%$ \\
& Service & 7 & $9 \%$ \\
& Transportation & 11 & $14 \%$ \\
& Livestock & 2 & $2 \%$ \\
& Age of business & 1 & $1 \%$ \\
\hline 2 & $5-10$ years & 50 & $63 \%$ \\
& $11-15$ years & 17 & $11 \%$ \\
& $16-20$ years & 9 & $5 \%$ \\
\hline \hline
\end{tabular}

The table above shows that business type of trading ranks the highest with $74 \%$, then services at $14 \%$, followed by accommodation and food and beverage business $9 \%$, then transportation $2 \%$ and then livestock $1 \%$. Based on the age of the business, the age of 5-10 years was $63 \%, 11-15$ years was $21 \%, 16-20$ years was $11 \%$ and businesses aged over 20 years old was $5 \%$.

\section{A. Descriptive Statistics}

Table IV shows that the intangible asset variable has a minimum score of 6 and a maximum score of 10 and an average score of 8.49 with a standard deviation of 1.232 . The mean with a score of 8.49 indicates that the intangible asset variable is in the 4 th scale range, which is agreed. This illustrates that respondents agree that the intangible asset variable contributes to their financial performance.

The financial resources variable has a minimum score of 4 and a maximum score of 10 and an average score of 6.35 with a standard deviation of 1.592 . This shows that the financial resources variable is in the 3 rd scale range, which means that the respondents quite agree if financial resources contribute to their financial performance. The regulatory variable has a minimum score of 5 and a maximum score of 10 with an average score of 8.04, standard deviations of 1.206 . This shows that respondents agree that regulatory variables contribute to their financial performance.
TABLE IV: DESCRIPTIVE STATISTIC TEST RESUlt

\begin{tabular}{ccccc}
\hline \hline Description & Minimum & Maximum & Mean & $\begin{array}{c}\text { Std. } \\
\text { Deviation }\end{array}$ \\
\hline Intangible Assets & 6 & 10 & 8.49 & 1.232 \\
Financial Resource & 4 & 10 & 6.35 & 1.592 \\
Regulation & 5 & 10 & 8.04 & 1.206 \\
$\begin{array}{c}\text { Financial } \\
\text { performance }\end{array}$ & 4 & 10 & 8.16 & 1.267 \\
\hline \hline
\end{tabular}

\section{B. Validity}

The instrument validity test was carried out in this study, in which $\mathrm{n}=80$ with a significance of $5 \%$, the value of $\mathrm{r}_{\text {table }}=$ 0.1829 , after the validity test was carried out, the calculated $r_{\text {value }}$ for all items ranged from 0.244 0.702 so that it is known that the value of $r_{\text {count }}>r_{\text {table }}$ means all statement items are declared valid and can be used as a data collection tool in research.

\section{Reliability}

From the results of the reliability test, it was obtained that Cronbach's Alpha was 0.747. Thus, it is known that 0.747 > $\mathrm{r}_{\text {table }}=0.1829$, meaning that the statement items in the questionnaire can be considered to be reliable as a means of collecting data in research.

\section{Data Analysis}

Before using the regression model, the classical assumption test was first tested, where this test aims to determine the feasibility of the regression model used in this study. The classical assumption test consists of Normality, Multicollinearity, Heteroscedasticity, and Autocorrelation tests.

\section{Normality}

In normality testing, the regression model must have residual data that is normally distributed. The normality test of the residual data in this study used the One-Sample Kolmogorov-Smirnov Test by looking at the Asymp value. Sig. (2-tailed). It is said to be normally distributed if the Asymp value. Sig. $>0.05$. The results of the normality test in Table $\mathrm{V}$ are as follows:

\begin{tabular}{cc}
\multicolumn{2}{c}{ TABLE V: ONE-SAMPLE KOLMOGOROV-SMIRNOV } \\
\hline \hline $\mathrm{N}$ & 80 \\
\hline Asymp.Sig (2-tailed) & 0,200 \\
\hline \hline
\end{tabular}

Based on the output above, it is known that the significance value of 0.200 is greater than 0.05 (table $=0.1829$ ) so it can be concluded that the data has been normally distributed.

\section{Multicollinearity}

The multicollinearity test aims to test whether there is a correlation between the independent variables in the regression model. It was found that a correlation between the independent variables. If there is no correlation between independent variables, the regression model is a good regression model. If there is no correlation between independent variables, the regression model is a good regression model. The variable is determined to have no multicollinearity if the level of tolerance value is $>0.01$ and the VIF value is $<10$. The results of the multicollinearity test are shown in the table below: 
TABLE VI: MULTICOLLINEARITY

\begin{tabular}{ccc}
\hline \hline Variable & Tolerance & VIF \\
\hline Intangible Assets & 0,596 & 1,678 \\
Financial Resource & 0,764 & 1,310 \\
Regulation & 0,734 & 1,362 \\
\hline \hline
\end{tabular}

Table VI shows that the tolerant value of the intangible asset variable is 0.596 , the financial resources variable is 0.764 and the regulatory variable has a tolerance value of 0.734 . The tolerance value obtained by the independent variable is less than 10.00 , so it can be concluded that there is no multicollinearity between the independent variables.

\section{Heteroscedasticity}

The significance value of the intangible asset variable is 0.928 , which is greater than 0.05 , meaning that there is no heteroscedasticity in the intangible asset variable. In the financial resources' variable where the significance value of 0.104 is greater than 0.05 , it means that there is no heteroscedasticity in this variable. Likewise, the regulation variable has a significance value of 0.753 , which is greater than 0.05 so that it is free of heteroscedasticity.

TABLE VII: HETEROSCEDASTICITY

\begin{tabular}{cc} 
TABLE VII: HETEROSCEDASTICITY \\
\hline \hline Variable & Sig. \\
\hline Intangible Assets & 0,928 \\
Financial Resource & 0,104 \\
Regulation & 0,753 \\
\hline \hline
\end{tabular}

Table VI shows that the tolerant value of the intangible asset variable is 0.596 , the financial resources variable is 0.764 and the regulatory variable has a tolerance value of 0.734 . The tolerance value obtained by the independent variable is less than 10.00 , so it can be concluded that there is no multicollinearity between the independent variables.

\section{Hypothesis Test Results}

Hypothesis test was conducted to find out how accurate the independent variables included in the model, financial resources, and regulations variables were able to explain the dependent variable, namely the financial performance variable. Hypothesis testing uses a probability level that is guided by the level of $5 \%$. If the significance value is $>0.05$, hence the hypothesis is rejected, whereas if the significance value is $<0.05$, hence the hypothesis is accepted.

\section{5. t-test (Partial)}

To determine whether the hypothesis is rejected or accepted, the $\mathrm{t}_{\text {test }}$ is carried out where the test criteria are used if the significant level is $>0.05$ hence the hypothesis is rejected, on the contrary if the significant level is $<0.05$ then the hypothesis is accepted.

\begin{tabular}{ccc}
\multicolumn{3}{c}{ TABLE VIII: T-TEST } \\
\hline \hline Variable & $\mathrm{B}$ & Sig. \\
\hline (Constants) & 1,010 & 0,189 \\
Intangible Assets & 0,622 & 0,000 \\
Financial Resource & 0,076 & 0,276 \\
Regulation & 0,293 & 0,002 \\
\hline \hline
\end{tabular}

Based on Table VIII, the test results using the t-test on the intangible asset variable obtained the regression coefficient (b) of 0.622 with a significance level of 0.000 . This study uses a significance level of 0.05 and the result of the significance is smaller than 0.05 so that it can be said that intangible assets affect the financial performance of small businesses. In financial resources, the $b$ coefficient value is 0.076 with $a$ significance level of 0.276 . The significance result is greater than 0.05 so that it can be considered that financial resources have no effect on the financial performance of small businesses. In the regulation variable, the $b$ coefficient value is 0.293 with a significance level of 0.002 . The significance result is less than 0.05 so that it can be considered that regulation affects the financial performance of small businesses.

\section{Goodness of fit model}

The F test basically shows whether or not the model used is good. The numerator's degree of freedom $(\mathrm{df}(\mathrm{n} 1))=\mathrm{k}-1$ where $\mathrm{k}=4$ (variable), while the denominator's degree of freedom $(\mathrm{df}(\mathrm{n} 2)=\mathrm{nk}$ (where $\mathrm{n}=80)$ hence $\mathrm{df}(\mathrm{n} 2=80-4=76)$ hence the calculated $F$ value is 31.945 with a significance value of 0.05 . The $F_{\text {table }}$ value obtained is 2.49 . It can be considered that calculated $F(31.945)>F_{\text {table }}(2.49)$ proves that this research model is good for use or has a good goodness of fit.

\begin{tabular}{ccc}
\multicolumn{3}{c}{ TABLE IX: FISHER TEST } \\
\hline \hline $\mathrm{F}$ & Sig & Result \\
\hline 31,945 & 0,000 & Accepted \\
\hline \hline
\end{tabular}

\section{Coefficient of Determination $\left(R^{2}\right)$}

Coefficient of Determination $\left(\mathrm{R}^{2}\right)$ intended to measure the ability of how big the percentage of variation of the independent variables in this case the variables of intangible assets, financial resources, and regulations in the multiple linear regression model in explaining the variation of the dependent variable in this case the financial performance variable.

\begin{tabular}{cc} 
TABLE X: COEFFICIENT OF DETERMINATION & $\left(\mathrm{R}^{2}\right)$ \\
\hline Model & $\begin{array}{c}\text { Adjusted } \mathrm{R} \\
\text { Square }\end{array}$ \\
\hline 1 & 0,540 \\
\hline \hline
\end{tabular}

The Coefficient of Determination Test it was obtained Adjusted R Square of $54 \%$. It indicated that $54 \%$ of the financial performance variables in small businesses can be explained by variations of three independent variables, namely intangible assets, financial resources, and regulations. Meanwhile, the other $46 \%$ was affected and can be explained by other variables excluded from the research model.

\section{CONCLUSION}

The results of this study indicate that intangible assets and regulations have a positive and significant effect on the financial performance of small businesses, while intangible assets have no effect on the financial performance of small businesses. From the regression results, it was found that the addition of intangible assets would increase more than six times in financial performance while the increase of regulations would increase the financial performance of small businesses twice. The Coefficient of Determination Test it was found that $54 \%$ of financial performance variables can be explained by intangible assets, financial resources, and 
regulations, while $46 \%$ can be explained by variables outside the model.

This study only examines the ability of small businesses to manage resources in an area, Balikpapan City. This study also does not describe MSMEs as a whole with the exclusion of micro and medium enterprises as the sample.

It is suggested that further study includes other variables other than Intangible Assets, Financial Resources, and Regulations. For further study use variable of mediating as a bridge so that variables that do not have an effect can have an effect and using the multivariate research methods.

\section{REFERENCES}

Ambrosini, V., \& Bowman, C. (2009). What are dynamic capabilities and are they a useful construct in strategic management? International Journal of Management Reviews, 11(1), 29-49. https://doi.org/10.1111/j.1468-2370.2008.00251.x.

Barney. (2007). Resource-Based Theory Creating and Sustaining Competitive Advantages. Oxford University Press.

El-Hamidi, F. (2011). How Do Women Entrepreneurs Perform? Empirical Evidence From Egypt. Economic Research Forum, Working Pa(23).

Fauzi, A., Suharjo, B., \& Syamsun, M. (2017). Pengaruh Sumber Daya Finansial, Aset Tidak Berwujud dan Keunggulan Bersaing yang Berimplikasi Terhadap Kinerja Usaha Mikro, Kecil dan Menengah di Lombok NTB. MANAJEMEN IKM: Jurnal Manajemen Pengembangan Industri Kecil Menengah, 11(2), 151-158. https://doi.org/10.29244/mikm.11.2.151-158.

Garengo, P., Biazzo, S., \& Bititci, U. S. (2005). Performance measurement systems in SMEs: A review for a research agenda. International journal of management reviews, 7(1), 25-47.

Ghozali, I. (2014). Structural Equation Modeling Metode Alternatif Dengan Partial Least Squares (PLS) (Edisi 4). Badan Penerbit Universitas Diponegoro.

Harash, E., Al-timimi, S., \& Alsaadi, J. (2014). Effects of Financing on Performance of small and medium enterprises (SMEs). IPASJ International Journal of Management (IIJM), 2(10), 1-9.

Koop, C., \& Lodge, M. (2017). What is regulation? An interdisciplinary concept analysis. Regulation and Governance, 11(1), 95-108. https://doi.org/10.1111/rego.12094.

Nangoli, S., Turinawe, D. D., Kituyi, G. M., Kusemererwa, C., \& Jaaza, M. (2013). Towards Enhancing Business Survival and Growth Rates in LDCs: An Exploratory Study of the Drivers of Business Failure among SMES in Kampala-Uganda. International Journal of Humanities and Social Science, 3(8), 284-291.

Peter, T., Sendawula, K., Pedson, T., \& Saadat, N. K. (2019). The joint effect of firm capability and access to finance on firm performance among small businesses: A developing country perspective. African Journal of Business Management, 13(6), 198-206. https://doi.org/10.5897/ajbm2019.8758.

PSAK. (2013). Pernyataan Standar Akuntansi Keuangan 1 (revisi 2009) (Statement of Financial Accounting Standards). Ikatan Akuntansi Indonesia.

Sugiyono. (2016). Metode Penelitian Kuantitatif, Kualitatif dan R\&D. PT Alfabeta Bandung.

Vijay, L., \& Ajay, V. K. (2011). Entrepreneurial Competency in SME? S. Bonfring International Journal of Industrial Engineering and Management Science, 1(Special Issue Inaugural Special Issue), $05-$ 10.https://doi.org/10.9756/bijiems.1002. 